\title{
The Dilemma of Australian Pacific Solution: The Non-Refoulement Principle Versus National Security
}

\author{
Ninin Ernawati* \\ DOI: https://doi.org/10.22304/pjih.v6n2.a7
}

Submitted: August 1, 2019 | Accepted: September 10, 2019

\begin{abstract}
The Australian Government has issued various policies to deal with refugees. One of the policies is the Pacific Solution and it is considered as a manifestation of national security principles. On one hand, the policy against the non-refoulement principle, which is the central principle of the refugee convention and Australia is one of the states that ratified the 1951 Refugee Convention. Obviously, Australia should not violate the non-refoulement principle. On the other hand, Australia has experienced a dilemma between prioritizing its interests and fulfilling international obligation to protect refugees who entering its territory. This article discusses whether the national security principle is contrary to the nonrefoulement principle; and how Australia can accommodate both principles without neglecting the rights of refugees and still be able to maintain their interests. This article also reviews how Australia can implement policies based on national security principle when it has to face international obligations-in this case, the non-refoulement principle. This research concludes that the national security and the non-refoulement principle are basically contradictory. However, Australia can accommodate these two principles by counterbalancing actions, such as the establishment of national laws that still highly consider humanitarian standards contained in the non-refoulement principle. Australia has the right to implement number of policies based on its national law, while that the same time Australia cannot ignore their international obligation to protect refugees in accordance with the 1951 Refugee Convention that they have ratified. Reflecting on some previous policies, this study concludes that Australia has not been able to accommodate both principles.
\end{abstract}

Keywords: National Security, Non Refoulement, Pacific Solution

\section{Dilema "Australian Pacific Solution": Prinsip Non-Refoulement Berhadapan dengan Keamanan Nasional}

\begin{abstract}
Abstrak
Pemerintah Australia telah mengeluarkan berbagai macam kebijakan untuk menangani kasus pengungsi. Salah satu kebijakannya adalah pacific solution. Kebijakan ini merupakan salah satu bentuk penerapan prinsip national security Australia. Di sisi lain, kebijakan ini

PADJADJARAN Journal of Law Volume 6 Number 2 Year 2019 [ISSN 2460-1543] [e-ISSN 2442-9325]

\footnotetext{
Magister candidate of the Faculty of Law, Universitas Padjadjaran, Jalan Dipati Ukur Nomor 35 Bandung, S.H. (Universitas Mataram), nininernawati70@gmail.com.
} 
dianggap melanggar prinsip non-refoulement, yang merupakan prinsip utama dalam konvensi pengungsi. Australia merupakan salah satu negara yang meratifikasi Konvensi Pengungsi 1951. Oleh karena itu, Australia seharusnya tidak melanggar prinsip NonRefoulement tersebut. Dalam menanggapi permasalahan tersebut, selama ini Australia mengalami dilema di antara mengutamakan negaranya atau menunaikan kewajiban internasional untuk melindungi pengungsi yang memasuki batas lautnya. Artikel ini mendiskusikan apakah prinsip national security tersebut bertentangan dengan prinsip nonrefoulement; dan bagaimana Australia bisa mengakomodasi kedua prinsip tersebut agar tidak menelantarkan hak-hak para pengungsi internasional dan tetap dapat melindungi kepentingan negaranya. Artikel ini juga akan mengulas bagaimana Australia dapat menerapkan kebijakan berdasarkan prinsip national security ketika harus menghadapi kewajiban internasional-dalam hal ini prinsip non-refoulement. Penelitian ini menyimpulkan bahwa prinsip national security dan prinsip non-refoulement pada dasarnya bertentangan. Akan tetapi, Australia dapat mengakomodasi kedua prinsip tersebut melalui tindakan penyeimbang, seperti pembentukan hukum nasional yang tetap memperhatikan standar kemanusiaan yang terkandung dalam prinsip non-refoulement. Australia berhak melaksanakan beberapa kebijakan yang tertuang dalam hukum nasional. Di sisi lain, Australia juga tidak dapat mengabaikan kewajiban internasional untuk melindungi pengungsi sesuai dengan Konvensi Pengungsi 1951 yang telah mereka ratifikasi. Berkaca pada beberapa kebijakan sebelumnya, kajian ini menyimpulkan bahwa Australia belum dapat mengakomodir kedua prinsip tersebut.

\section{Kata Kunci: Keamanan Nasional, Non-Refoulement, Pacific Solution}

\section{A. Introduction}

Non-refoulement is a fundamental principle in international refugee law. The principle gives a person protection from being returned to their home country where they may face torture, harassment, or another mistreatment. The prohibition to return refugees is contained in several international convention regarding refugee, human rights, and customary international law. Scholars argue that these rules have even reached the status of a fundamental norm or peremptory norm. ${ }^{1}$ Although there are exceptions to the right "not to return" in the Refugee Convention of 1951, the ICCPR stipulates that the non-refoulement principle is an absolute and non-derogable right.

Given the number of threats posed by the increasing number of refugees who want to enter Australia, the Australian Government has a dilemma in determining the policies that must be taken. Given the modern threat of global terrorism, many states have adopted "balancing measures" between refugee interest and national security issues. However, there is no international consensus on the permissibility of balancing actions that consider the interest of refugees against the security interest of a state. In this case, the UNHCR permits a balancing approach through Article 33 (2) of the 1951 Refugee Convention. Whilst, the International Covenant

\footnotetext{
Irawati Handayani, "Jus Cogens-International Law and Social Contract," Book Review, Padjadjaran Jurnal IImu Hukum, Vol. 3, No. 3, 2016, p. 652.
} 
of Civil and Political Rights, the United Nations Human Rights Committee, and the European Court of Human Rights rejected the method. These two principles give the Australian Government a policymaking dilemma, whether to prioritize refugees, which are an international obligation, or state security, which is the state's obligation to protect the state from various threats.

Displacement is a form of population movement that has different characteristics from other forms of population movement. Such characteristics distinguish refugees from other categories of migrants and affect the protection mechanisms applied to them. ${ }^{2}$ A movement of population, both within national territory and crossed national borders, is an event that has long existed in human history and is increasingly happening now. ${ }^{3}$ From the perspective of recipient state, refugee flows aside from being a humanitarian issue that also have an impact on the security, economic, and social political balance. ${ }^{4}$ Internal problems in a state and lack of international assistance for refugees result in more and more states closing their borders from a large influx of refugees. ${ }^{5}$ One of the states that closes its border is Australia. Australia is a paradise of international refugees. However, it has struggled with efforts to adopt various policies to deal with asylum seekers who come by boat, also known as the Boat People. ${ }^{6}$

Australia has ratified the 1951 Refugee Convention; therefore, Australia has an obligation to accept all asylum seekers who wish to obtain refugee status in their country. However, in practice, Australia has denied the mandate given by the Refugee Convention. The Australian Government has argued that their actions in protecting their maritime boundary are legitimate based on national security principles. However, the big question arises: to what extent can a state apply national security principles when it clashes with international obligations to protect refugees? The international obligations refer to the obligation of the Australia to protect the lives of refugees whose life are threatened at seas if they are not allowed to enter the Australian territory. The right to life is a non-derogable right. Therefore, the Australian government has an obligation to save the lives of the asylum seekers.

This paper presents data related to the number of immigrants entering Australia as well as the number of victims who have lost their lives due to policies established by Australia based on their national security principles. In 2008-2009,

2 Jovan Patrnogic, "Introduction to International Refugee Law", Paper Presented at Refugee Law Courses, the International Institute of Humanitarian Law, San Remo-Italy, 1996, p. 9.

3 Myron Weiner, "Bad Neighbors, Bad Neighborhoods: An Inquiry into the Causes of Refugee Flows," International Security, Vol. 21, No. 1, 1996, pp. 5-42.

4 Gill Loescher, Beyond Charity: International Cooperation and the Global Refugee Crisis, New York: Oxford University Press, 1996, p. 11.

5 UNHCR, The State of the World's Refugees 1997-1998, A Humanitarian Agenda, New York: Oxford University Press, 1998, p. 51.

6 Danang Fery Anggriawan, "Pelanggaran Prinsip Non-Refoulment terhadap Pengungsi dan Pencari Suaka pada Kebijakan Operation Sovereign Borders serta Implikasinya bagi Indonesia sebagai Negara Transit," Journal of International Relations, Vol. 2, No. 4, 2016, p. 255. 
the estimated number of refugees entering Australia increased to $300,000 .^{7}$ Previously, in 2004-2005, the number of immigrants and refugees who entered is only $123,424 .^{8}$ The latest data from The Refugee Council of Australia, in 2012, there are 17,202 refugees. ${ }^{9}$ The increasing number of immigrants and refugees, over a four-year period of more than $100 \%$, has increasingly influenced the Australian reform on immigration policies.

The consequence of these policies is expulsions of asylum seekers who wish to enter Australia in the high seas, causing many deaths in the middle of the sea. In August 2001, the Howard Government refused permission to the Norwegian freighter MV Tampa, which carried 438 refugees (mainly the Hazara from Afghanistan rescued from a depressed fishing boat in international waters) into Australian waters. This sparked Australian political controversy in leading up to federal elections and diplomatic disputes between Australia and Norway. When Tampa entered Australian water, the Prime Minister ordered the ship to be boarded by Australian Special Forces. This brought condemnation from the Norwegian government, which declared the Australian government failed to fulfill its obligations under international law.

Within days, the Australian Government introduced the Border Protection Bill to the Parliament saying it would confirm Australia's sovereignty to "determine who will enter and live in Australia". The government introduced the so-called Pacific Solution. The solution requires asylum seekers to be brought to Nauru. There, refugee status is processed and determined, not in Australia. Another case to mention here is when the Australian navy drove a ship that was going to enter Australia to return to Indonesian waters. The ship sank in Indonesian waters, near Cianjur, and caused 15 deaths and 6 of them were children. ${ }^{10}$ In addition, the same incident also occurred in Cidaun, Java waters where about 100 people were pulled out of the waters. ${ }^{11}$ It is estimated that 170 people took part in the dangerous journey. Finally, four people were dead when a ship carrying 150 asylum seekers sank on Christmas Island. ${ }^{12}$

The Pacific Solution policy began to be implemented in September 2001. ${ }^{13}$ This policy was implemented to stem the number of refugees entering Australia from

\footnotetext{
David Whittaker, Asylum Seeker and Refugees in the Contemporary World, New York: Routledge, 2006, p. 76. Katherine Betts, "Boat People and Public Opinion in Australia", People and Place, Vol. 9, No. 4, 2001, p. 34. Ibid.

BBC News, "Kapal Pencari Suaka Tenggelam di Perairan Jawa”, https://www.bbc.com/indonesia/dunia/2013/07/130724_pencari_suaka_australia, downloaded on 28 July 2019.

11 Yasniar Rahmawati M. Ikaningtyas, "Penanganan Kejahatan People Smuggling yang Melibatkan Warga Negara Asing melalui Jalur Laut", Paper presented at Proceeding Interdisciplinary Studies Seminar "Peningkatan Pertahanan Maritim dan Kerangka Diplomasi Perbatasan dan Ketahanan Nasional Indonesia", Malang, 9 December 2017.

13 Hardi Alunaza, Ireng Maulana, and Adityo Darmawan Sudagung, "The Pacific Solution as Australia's Policy towards Asylum Seeker and Irregular Maritime Arrivals (Imas) in the John Howard Era",
}

$12 \quad$ Ibid, p. 3. 
waters. The Pacific Solution policy consists of three main strategies: (1) removing thousands of islands from Australian migration zones, or Australian territory; (2) the Australian Defense Force's Operation Relex to intercept ships carrying asylum seekers; and (3) asylum seekers were moved to detention centers in Nauru and Papua New Guinea for the determination of refugee status. ${ }^{14}$

The international law cannot justify Operation Relex in this policy because it can endanger the lives of refugees who need protection. ${ }^{15}$ In any case, a state cannot return refugees who are in a state of fear because of the threats in their home country. This principle is known as the non-refoulement principle. The nonrefoulement principle is a basic principle of international law, which gives a person protection from being returned to a place where they face risks of threat, torture, or other mistreatment. ${ }^{16}$ The refoulement ban is recognized by the 1951 Refugee Convention (Art. 33[1]), UNHCR, Basic legal Documents on Refugees (1999), 9-37; Article 3, United Nations Declaration on Territorial Asylum; Article VIII of the AsianAfrican Legal Consultative Committee, Bangkok Principles; Art. II(3), OAU Convention 1969; and Article 22(8), American Convention on Human Rights Convention (1969). ${ }^{17}$

As the contracting state of refugee convention, Australia must carry out the mandate of the convention. However, Australia conducted some activities against it, due to the fact that Australian tends to secure its country from a variety of criminal offenses that allegedly will emerge as more immigrants enter their territory. Australia's policy is based on the principle of National Security. Australia's concerns and actions are certainly based on allegation since there is a growing incidence of terrorism in Muslim-majority countries where most of the refugees come from -such as Syria, Afghanistan, Myanmar (the Rohingya Muslims). This fact triggered fears within the Australian Government and some of the Australian community. It can be observed from a survey conducted by the Australia's refugee council to community agreement on the presence of refugees in Australia. The survey shows that the majority of native Australians reject the presence of refugees in Australia. ${ }^{18}$ An extremely horrific act of terrorism in two mosques in New Zealand, Australia's closest neighbor, on Friday, $15^{\text {th }}$ of March 2019, was carried out

https://media.neliti.com/media/publications/238227-the-pacific-solution-as-australia-policy-e4ae21d2.pdf, downloaded on 18 July 2019.

14 Evan Williams, "Australian Immigration 2001-2013 Exploring Attitudes towards Asylum Seekers and Immigrants", Thesis, The Australian National University, 2018, p. 114.

15 Ingrid Holm, "Non-Refoulment and National Security," Thesis, Faculty of Law Lund University, 2015, p. 13.

16 Sigit Riyanto, "Urgensi Legislasi Hukum Pengungsi dan Kendalanya di Indonesia", Indonesian Journal of International Law, Vol. 2, No. 1, 2004, p. 70.

17 Ayub Torry dan Satriyo Kusumo, "Perlindungan Hak Asasi Manusia Pengungsi Internasional”, Yustisia, Vol. 1, No. 2, 2012, p. 174.

18 Janet Phillips, "Social Policy Section on Refugees: Australia's humanitarian response", https://www.aph.gov.au/About_Parliament/Parliamentary_Departments/Parliamentary_Library/pubs/Briefin gBook43p/refugees, downloaded on 28 July 2019. 
by radical Australian white supremacists. ${ }^{19}$ Still, some Australian Government officers, such as the Queensland's Senator Fraser Anning, argue that the perpetrators could have been from Muslims themselves. In fact, the victims are Muslims. Anning's also states that the Muslims are part of immigrants who entered the territory of Australia and the cause of the brutal action was due to the increasing number of immigrants entering Australia. ${ }^{20}$

Australia's policies are followed up through the National Security Principles, which refer to public policies, to ensure the safety and the security of the country by economic and military power and diplomacy, both in peace and war. ${ }^{21}$ Considering the national security, the government intended to protect public from disruption caused by disaster or crisis. National security strategy requires a state examines threats, preventions, and plans in the event of a disaster. National security is at stake when one or more of the state's vital interests are threatened. A state's national security must achieve several aspects. ${ }^{22}$ The first is territorial security. Territorial security deals with threats of military occupation and natural disasters like prolonged flooding. The second is economic security. Major disruptions to the internet or electricity will disrupt online financial transactions. The third is ecological security. Environmental damage due to pollution or extreme heat or drought. The fourth is physical security. Death, injury and chronic illness caused by floods or pandemics. The fifth, the last, is social and political stability security. It deals with violations of the rule of law caused by tensions between people. It is also to analyze, to compare, and to handle threats.

This article tries to reveal whether the national security principle is contrary to the non-refoulement principle. It also covers the possibility for Australia to accommodate the two principles and enable them not to neglect the rights of international refugees and to still be able to protect their country. In addition, the article also seek to what extent can Australia implement policies based on national security principles when dealing with international obligations -in this case, the non-refoulement principle.

\section{B. Non-Refoulement Principle}

The non-refoulement principle reflects the minimum protection based on humanitarian reasons. It is stated in Article 33 of the 1951 Refugee Convention.

19 Ardi Priyatno Utomo, "Kabar Aksi Terorime di Dua Masjid Australia," https://internasional.kompas.com/read/2019/03/16/16574721/bikin-pernyataan-yang-menyalahkan-muslimsenator-australia-ini-dilempar, downloaded on 20 July 2019.

20 The Guardian, "Fury as Australian senator blames Christchurch attack on Muslim immigration", https://www.theguardian.com/world/2019/mar/15/australian-senator-fraser-anning-criticised-blaming-newzealand-attack-on-muslim-immigration, downloaded on 28 July 2019.

21 Roger, “Apa Yang Dimaksud dengan Keamanan Nasioanl (Nasional Security)?”, https://www.dictio.id/t/apayang-dimaksud-dengan-keamanan-nasional-national-security/4611, downloaded on 18 July 2019.

22 Government of the Netherlands, "Counter Terrorism and National Security Netherland", https://www.government.nl/topics/counterterrorism-and-national-security/national-security, downloaded on 20 July 2019. 
The Article 33 covers several important points. ${ }^{23}$ First, the convention only binds states that have become parties to the convention. Based on Article I, Paragraph (2), of the 1967 Protocol, a state, which is not a party to the 1951 Refugee Convention but is a party to the Protocol is also bound by Article 2 to Article 34 of the 1951 Refugee Convention. Therefore, Article 33 of the 1951 Refugee Convention binds states that are parties to in the 1951 Convention and/or the 1967 Protocol or both instruments. ${ }^{24}$ Second, the 1951 Refugee Convention concerns on humanitarian issues. This is clearly stated in the opening paragraph that the United Nations concern on refugees and guarantees refugees' basic rights and freedoms as referred in the Universal Declaration of Human Rights. This is an acknowledgment by all states on the social and humanitarian aspects of the refugee problem. Third, the prohibition of expulsion contains specific condition. Article 42, Paragraph (1), of the 1951 Refugee Convention excludes Article 33 from the reservation act and, therefore, supports this. Thus, the ban on eviction in Article 33 of the convention is a non-derogable obligation, which builds the essence of humanity in the 1951 Refugee Convention. Article VII, Paragraph (1), of the 1967 Protocol, reaffirms the non-derogable nature of the ban on eviction. The non-refoulement principle has been considered as customary international law. It means that all states, whether they have been state parties or not of the conventions of refugee and/or human rights that prohibit evictions, are obliged not to return or extradite someone to a state where they live is truly in danger. ${ }^{25}$

Peremptory norm, or also called jus cogens (from Latin, which means coercive law), is a basic principle of international law that is accepted by states as a norm that cannot be reduced in its implementation. ${ }^{26}$ As peremptory norm or jus cogens, the non-refoulement principle must be respected in all circumstances and cannot be changed. These fundamental rights and principles have been held for the benefit of all people regardless of whether the state has been a party to the 1951 Refugee Convention or not and regardless of whether the person has been recognized as a refugee or not. ${ }^{27}$

The non-refoulement principle is not absolute. This principle can be derogated if the refugee threatens national security or disturbs public order in the state of destination where he is seeking protection. This is stated clearly in Article $1 \mathrm{~F}$ and Article 33, Paragraph 2, of the 1951 Refugee Convention. According to both articles, the prohibition of forcing refugees to return to a state where they may

23 Guy S. Goodwin-Gill, "Article 31 of the 1951 Convention relating to the Status of Refugees: Non-penalization, Detention and Protection", https://www.unhcr.org/3bcfdf164.pdf, downloaded on 17 July 2019.

24 Jun Justinar, "Prinsip Non-Refoulement Dan Penerapannya di Indonesia”, p. 3, https://pustakahpi.kemlu.go.id/app/Volume\%203,\%20September-Desember\%202011_18_23.PDF, downloaded on 28 July 2019.

25 UNHCR, "Refugee Protection: A Guide to International Refugee Law," 1 December 2001, https://www.refworld.org/docid/3cd6a8444, downloaded on 16 October 2019.

26 Sigit Riyanto, "Prinsip Non-Refoulement dan Relevansinya dalam Sistem Hukum Internasional”, Jurnal Mimbar Hukum, Vol. 22, No. 3, 2010, pp. $434-449$.

27 Jun Justinar, op.cit., p. 5 . 
experience persecution is not applied to refugees who threaten security the state, or the refugees who received a final verdict from the judge for the serious crime they have committed, as well as endangering the local state community. However, this provision has a high threshold. It means, if the exception is to be applied, it must be proven that there is a direct relationship between the existence of refugees and the national security. ${ }^{28}$ Such displacement of refugees will only be carried out as an implementation of a decision reached in accordance with due process of law. Unless compelling national security reasons require otherwise, the refugee should be permitted to submit evidence for self-defense and to appeal to the competent authority. ${ }^{29}$

The exception to the non-refoulement requires an element of threat to state security and disruption to public order in the host country. For all countries, security is not only in the context of a country's internal security but also in the system of food, health, finance, and trade. ${ }^{30}$ Threats include obstacles, challenges, and disturbances. ${ }^{31}$ In a narrow sense, threats can be planned or residual in nature. Planned threats can be in the form of domestic subversion or rebellion or infiltration, subversion, sabotage, and invasion. Residual threats are various conditions in society that constitute economic, social and political vulnerabilities, which, if it is not dealt with in a timely manner, will trigger riots used by subversion or rebel elements for their interests. ${ }^{32}$

It is understandable that a large influx of refugees can burden the economy, change ethnic balance, and become a source of conflict. It can even cause political chaos at local and national levels. ${ }^{33}$ Lippmann, quoted by Anggoro, states that a country is in a safe condition as long as the nation cannot be forced to sacrifice the values it deems important (vital) and if it can avoid war or if forced to fight, it can come out as a winner. ${ }^{34}$ On the other hand, public order is a condition where the government and the people can carry out activities in an orderly manner. ${ }^{35}$

\footnotetext{
28 Human Rights Watch, "Human Rights Implications of European Union Internal Security Proposals and Measures in the Aftermath of the 11 September Attacks in the United States", www.hrw.org/press/2001/11/eusecurity-memo.htm, downloaded on 12 July 2019.

29 See Article 32(2) of the Convention Relating to the Status of Refugees 1951.

30 J. Ann Tickner, "Re-visioning Security", in International Relations Theory Today, compiled by Ken Booth and Steve Smith, (eds.), Cambridge: Polity Press, 1994, p. 180.

31 Sjaafroedin Bahar, (et.al), Pendidikan Pendahuluan Bela Negara Tahap Lanjutan, Jakarta: Intermedia, 1994, p. 68.

$32 \quad$ Ibid., p. 71.

33 Myron Weiner, op.cit., p. 131.

34 Kusnanto Anggoro, "Keamanan Nasional, Pertahanan Negara dan Ketertiban Umum", Paper Presented at Seminar Pembangunan Hukum Nasional VIII by Badan Pembinaan Hukum Nasional, Departemen Kehakiman dan HAM RI, Denpasar-Bali, $14^{\text {th }}$ of July 2003 , p. 2.

35 See Article 1(5) of Local Regulation DKI Jakarta Number 8 of 2007 on Public Order.
} 


\section{National Security Principles}

The discussion of the national security system has been going on for decades. ${ }^{36}$ One of the main principles of national security in every modern democratic country is the rule of law. ${ }^{37}$ Buzan divides security into military, political, environmental, economic, and social. ${ }^{38}$ Military approach means only one of them in the national security system. The role of the military is focused on the capabilities of defense institutions, threat assessment, and others. This implies a standard definition relating to the state and national vital values and the standard for the existence of mechanisms and organizations of security (the formation of law, jurisdiction, duties, authority, responsibility, and control). They are included in national law (constitution, statutory regulation laws and by laws), as well as international law (conventions, resolutions, charter, agreements, recommendations, decisions of international courts, commissions, and arbitration bodies, etc.). In general, in democracy, national law is based on international law. In this case, it is possible to consider that international law based on national security, which establishes a framework for the proclamation, regulation, and protection of state values.

National security can also be defined as an effort to maintain the survival of the nation and state, which includes territorial integrity, constitutional life, and the survival of citizens. ${ }^{39}$ Classic national security is intended to maintain the continuity of the state as an independent entity that is separated from the collection of its citizens. State is established to guarantee individual security of all citizens who through a social contract have given up some of their sovereignty to be granted to the state in exchange from order and security provided by the state. ${ }^{40}$ Thus, it can be said that the ultimate purpose of national security is to guarantee security of individuals who live in state through state defense as a socio-political institution that guarantees order and security for citizens. In this regard, Lauterpacht and Bethlehem state in their comments related to the interpretation and the application of national security exceptions contained in Article 33(2). First, the nature of the exclusion is clear and prospective, and certainly the prospective question is still relevant. Moreover, the danger in question is truly a danger that will cause national security from the country where the refugees are located. The exception does not relate to the prospect of danger to the security of other

\footnotetext{
36 Sidratahta Mukhtar, "Keamanan Nasional: Antara Teori dan Prakteknya di Indonesia”, http://ejournal.uki.ac.id/index.php/sp/article/view/466, downloaded on 18 July 2019.

37 Shirin Sinnar, "Rule of Law Tropes in National Security", http://cdn.harvardlawreview.org/wpcontent/uploads/2016/04/1566-1618-Online.pdf , downloaded on 17 July 2019.

38 Barry Buzan, People, States and Fears, an Agenda for International Security Studies in Post-Cold War, Boulder: Lynne Rienner Publishers, 1991, p. 8.

39 Makmur Keliat, "Keamanan Maritim dan Implikasi kebijakannya bagi Indonesia," Jurnal IImu Sosial dan Politik, Vol. 13, No. 1, 2009, p. 125.

40 Edward N. Zalta (ed.), "Contemporary Approaches to the Social Contract", The Stanford Encyclopedia of Philosophy (Winter Edition), https://plato.stanford.edu/entries/contractarianism-contemporary/\#Distinct, downloaded on 16 August 2019.
} 
countries or the international community as a whole. ${ }^{41}$ According to Lauterpacht and Bethlehem, such interpretation would be incompatible with the nature of humanity and the fundamental non-refoulement prohibition. This interpretation is supported by the development of the application of non-refoulement as an absolute right in human rights law, regardless of the individual's behavior. However, in the very famous Suresh Case, the Supreme Court of Canada rejects this approach. The court stated that the national security of a country must depend or be based on the security of another country. ${ }^{42}$ The decision referred to the big incident at September 11, 2001 in the USA. In its decision, the court stated that the notion of terrorism in a country had no implications for other countries was no longer valid. Although there are exceptions in Article 33(2), there is a need because of danger to the state providing protection against refugees. Although the change in the nature of national security changes after $11 / 9$, it is likely that only the negative consequences are insufficient to implement national security exceptions.

To achieve the objectives, state, through its various state institutions, carries out a national security management. Various implementing actors have specialized functions and tasks. In the case of national security implemented by Australia, it was taken over by the Australian Defense Force which tasked to secure the Australian maritime border. Holders of power (state), to justify acts of violence that demean human dignity, including those against political opponents or parties who disagree with them, often use the term 'national security'. Another example was when the USA established a detention camp at Guantanamo Bay that is outside the jurisdiction of the US Supreme Court and detained about 300 people with no litigation process. It carried out interrogation techniques that included torture, one of which is waterboarding (which was once practiced by the Gestapo). In addition, the USA also carried out an "extraordinary rendition," the transfer of terrorist prisoners to countries that have a very poor human rights record to prevent the country from obligations to respect human rights. ${ }^{43}$ Then again, various antiterrorism legislations are enacted in many countries (even in liberal democracies). The legislations give so much power to the state to do things that have the potential to interfere with the security of individual citizens, such as the authority to conduct surveillance and wiretapping, limiting the rights of citizens before the law, to the elimination of the right to life. They all are performed in the name of national security. ${ }^{44}$ This also happened at the detention camps in Nauru and Papua New Guinea. These two states serve as temporary shelters for asylum

41 Sir Elihu Lauterpacht and Daniel Bethlehem, "The Scope and Content of the Principle of Non-Refoulement: Opinion", https://www.unhcr.org/419c75ce4.pdf, downloaded on 18 July 2019.

42 Supreme Court of Canada, Suresh v Canada, Judgement, 2002, para. 87.

43 Chris Brown, "Human Rights" in The Globalization of World Politics by John Baylis, (et.al.), Oxford: Oxford University Press, 2008, p. 508.

44 Ben Golder, Balancing National Security and Human Rights: Assessing the Legal Response of Common Law Nations to the Threat of Terrorism," Journal of Comparative Policy Analysis: Research and Practice, Vol. 8, Issue 1, 2006, p. 45. 
seekers who wish to apply for refugee status to the Australian Government. However, the time needed for this process is relatively long. Asylum seekers need years in shelter camps waiting their turn to be determined whether they have the refugee status or not. If they obtain the refugee status, they can enter Australia. If their application is not approved, they will be returned to their country or departed to a third country.

Article 33 (2) does not specify any actions that are categorized as exceptions in prioritizing national security and intended standards. The only scope that can be used as a reference in the convention is the reasonable grounds/underlying reasons, which should be proven. On the contrary, Lauterpacht and Bethlehem state that states could only implement limited actions in this case. State cannot act arbitrarily because there must be a reason to declare that a refugee potentially endangers national security. Government must assess the danger and provide evidence to state that the refugee might be a threat. On this basis, human rights law experts consider that to avoid arbitrary steps in maintaining national security, all policies and practices of national security management should be based on human rights standards, rule of law, and democracy. In this context, the principles and rules of human rights become safeguards, so the management and the implementation of national security does not violate its highest goal to protect security of citizens. From this perspective, national security and human rights may still be in line. On the one hand, certain rights (for example right to privacy and due process of law) can be limited if there are public emergencies that threaten national security. Due process of law means that the Australian Government should have conducted a hearing process in determining status of refugees who will enter their territory to continue to provide justice for asylum seekers. To secure the state, the process will certainly be guaranteed and will not provide an opportunity for perpetrators of crime to enter the territory. On the other hand, human rights principles set limits of national security (in the form of non-derogable rights, such as the right to life and the right to be free from torture), so the implementation of national security does not betray its true objectives. ${ }^{45}$

It can be concluded that there are two reasons for the management of national security to consider the principles of human rights by not returning asylum seekers back to their native countries or letting them drift offshore. First, deontologically, the state has a moral obligation to maintain the security of its citizens based on the social contract on which it was founded. The maintenance of security also includes respecting and protecting human rights of every citizen. ${ }^{46}$ If the state fails to comply this, the establishment rationale and its sustainability will automatically vanish. Second, instrumentally, human rights principles play a role as safeguards to

45 See Article 17(1), Article 7, and Article 18(1) of International Covenant on Civil and Political Rights 1969.

46 Irawati Handayani, "Accountability for Human Rights Atrocities in International Law: Finding Justice For Past Human Rights Abuses", Master Thesis, Master's Programme In International Human Rights Law, Faculty of Law, Lund University, 2006, p. 11. 
ensure that the management of national security truly achieve the highest and true goal to protect whole nations and citizens from various threats that may prevent them from living with dignity, including threats that come from the country itself.

\section{Application of National Security Principles through Securitization of Migration in Several Countries}

The theory of securitization and the studies of development of migration securitization began in Europe and was coined by Copenhagen School thinkers such as Ole Waever and Barry Buzan. The definition of securitization in this theory is the construction of a problem into a security issue by using the speech act. Subsequently, it creates ideas or discourse of problems to be handled. It can be said that securitization is an extreme form of politicization.

The securitization theory sees the function of speech act to influence social and linguistic theories in the development of international relations. Here, the issue of security, specifically how to make an issue a security issue, is not only seen from the viewpoint that state has national interests. Instead, this theory wants to say that there is a rhetorical production process for a problem as a matter of state security. Furthermore, Leonard explains that because a threat is something that is socially constructed, it becomes impossible to determine whether the threat is real or not. ${ }^{47}$

In the context of migration, migration securitization can be found in the perception of the presence of foreigners, which may threaten community in terms of socio-economic, security aspects (state sovereignty ${ }^{48}$, national borders, and internal and external security), in terms of identity (identity and demographic hazards), and political aspects (racism, anti-immigrants). Huymans further explains that there are three steps of securitization to realize the perception. ${ }^{49}$ They are:

(1) Spread of fear and trust;

(2) Managing inclusion and exclusion process; and

(3) Institutionalization of alienation and inculcation of violence.

Securitization of migration and security threats from immigrants are not natural. This theory is constructed based on rhetorical arguments of politicians, security agencies, and media through text, language in policy, legal products, and public statements. ${ }^{50}$

\footnotetext{
47 Sarah Leonard, "The Use and Effectiveness and Migration Controls as a Counter-Terrorism Instrument in the European Union", Central European Journal of International and Security Studies, Vol. 4, Issue 1, 2010, p. 32.

48 Irawati Handayani, "Responsibility to Protect: A New Form of Humanitarian Intervention?", Padjadjaran Journal of International Law, Vol. 1, No. 1, 2017, p. 53.

49 J. Huysmans, "The European Union and the Securitization of Migration", Journal of Common Market Studies, Vol. 38, No. 5, 2000, pp. 751-777.

50 Ayse Ceyhan, and Anastassia Tsoukala, "The Securitization of Migration in Western Societies: Ambivalent Discourses and Policies." Alternatives Vol. 27, No. 1, 2002, pp. 21-39.
} 
Guild further explains the securitization of post-suicide bombing carried out by the Al-Qaeda group on September 11, 2001 or commonly called the 11/9 attacks constructing the nexus between terrorism with forced migration and asylum policies. ${ }^{51}$ In the United States, there is a view that there is a direct connection between foreigners, especially from Islamic countries, with the threat of terrorism. It later became the center of security policy-making in Western countries. Here, securitization is manifested in the variety of migration policies that are directly connected with policies against terrorism such as War on Terrorism run by the United States. ${ }^{52}$ Shortly after the events of $11 / 9$ in the United States, a law was passed to give the United States Department of Justice authority to detect, to deport, or to exclude foreigners suspected of terrorist activities. ${ }^{53}$

In the European Union, refugees and asylum seekers have long been seen as a threat to countries since most of them come from Muslim majority countries with identities that are in contrast to European identities. After 9/11 incident, policies to strengthen border controls are seen as a crucial part of European anti-terrorism policy. ${ }^{54}$ Late 2001 in the UK, the 2001 Anti-Terrorism, Crime, and Security Act was enacted. Based on the law, the Home Secretary has the authority to detect and to exclude suspected terrorists from the refugee's determination status (RSD) process. In Germany, the war on terrorism is carried out by tracing origin and whereabouts of people. In the Netherlands, asylum seekers' fingerprints are used in the asylum application process to check criminal records. ${ }^{55}$

In Australia, The Minister of Defense, Peter Reith, stated that it was very possible for terrorists to enter Australia by boat. Even before 11/9 incident, Australia had enacted the migration securitization in the mandatory detention policy, the separation of humanitarian policy from migration policy, and temporary visa regulations for migrants who came without documents or not through official channels. ${ }^{56}$ The crime-terror nexus and cross-border refugee trends continued until recently the United States government under Donald Trump issued a policy prohibiting migration from Islamic countries. This policy raised or reaffirmed that terrorism is attached to Muslim communities, so it needs to be strictly regulated the entry of Muslims into the United States. This policy is a further problem due to the high number of world refugees from Islamic countries caused by conflicts within or involving their countries. The same thing also happened in Europe when the surge of Syrian refugees increased. Herta explains the securitization of Syrian refugees in the United States and Europe by referring to public statements made by

\footnotetext{
B. Gokay and R.B.J. Walker, War, Terror and Judgement, London: Frank Cass Publisher, 2005, p. 34.

52 Elspeth Guild, "Anti- \& Counter- Terrorism and Human Rights In Europe", https://www.qmul.ac.uk/law/media/law/docs/events/QMUL-Report-July-2018.pdf, downloaded on 17 July 2019.

53 B. Gokay and R.B.J. Walker, op.cit, p. 36.

54 Sarah Leonard, op.cit., p. 50.

55 B. Gokay and R.B.J. Walker, op.cit., p. 180.

56 M.J. Gibney, The Ethics and Politics of Asylum, Cambridge: Cambridge University Press, 2004, p. 62.
} 
US President Donald Trump and Hungarian Prime Minister, Viktor Orban. ${ }^{57}$ Donald Trump said cross-border refugees needed to be questioned about their views on honor killings and radical Islam. Orban said that accepting cross-border refugees was tantamount to "importing crime, terrorism, and homophobia". ${ }^{58}$

Securitization of cross-border refugees is a problem because their movements involve human rights issues. Cross-border refugee movement (referring to both asylum seekers and cross-border refugees who have gone through a process at the UNHCR) belongs to forced migration groups due to violent conflicts or threats that endanger their lives. Their movement and protection have been regulated in international law, the 1951 Refugees Convention. The nexus of cross-border refugee and terrorism is baseless and can endanger cross-border refugees. There has been an appeal from the UN not to continue using this rhetoric because the securitization of cross-border refugees not only endangers the human rights aspects of refugees but also for the destination country. Ben Emmerson, special rapporteur on counterterrorism and human rights in 2016 report at the UN General Assembly explains, "There is no evidence that migration has increased terrorism activities. On the contrary, restricting or violating human rights migration policies can create conditions conducive to the development of terrorism" ${ }^{59}$

It can be concluded that each country has unique forms of national security implementation that different to others. In this topic, uniqueness is related to national laws to manage the number of cross-border refugees entering state's territory. Through national laws, each country forms a policy that provides close supervision in border regions. Australia has established regulations of maritime boundaries through sovereign borders and pacific solution policies. The United States has formed its national security policy through the securitization of the migration ban on refugees from Islamic countries. President Donald Trump reiterates that terrorism is closely attached to Muslim societies, so the United States needs to strictly regulate the entry of refugees from Muslim countries. ${ }^{60}$

As explained above, the definition of national security principle is an effort to maintain survival of nation and state, which includes territorial integrity, constitutional life, and citizens. ${ }^{61}$ In general, the application of national security must have threshold because the fundamental character of the non-refoulement principle and the humanitarian character in the 1951 Refugee Convention. However, Lauterpacht and Bethlehem do not specify the level of danger to a state's security in the future than a general term 'a serious threat'. They state that the threshold of danger contained in Article 33(2) is higher than the danger contained

\footnotetext{
57 Laura Herta, "Security as Speech Act: Discourse Construction on the Syrian Refugee Crisis," in International Conference on Redefining Community in Intercultural Context, Bari, 5-6 June 2017, pp. 283-287.

58 Laura Herta, op.cit., p. 290.

59 OHCHR, 2016

60 Nurul Azizah Zayzda, "Sekuritisasi Migrasi Paksa Pengungsi Lintas Batas Indonesia", Journal of Seminar Nasional Hukum Universitas Negeri Semarang, Vol. 3, No. 1, 2017, pp. 43-45.

61 Makmur Keliat, op.cit., p. 129.
} 
in Article 1f, which is related to criminal acts committed by refugees. Consequently, the interpretation of the word "danger" in Article 33 (2) is not appropriate if the intended danger is not too serious. As has been explained previously, the Australian Government prevents the event of a terrorism as the one that occurred in New Zealand a few months earlier so that they apply a strict screening of refugees who sought refuge in their territory.

Based on the discussion, the application of national security through migration securitization of each state to protect its borders is only a form of justification to limit refugees who enter their territory. Australia, which is a country that has ratified the convention on refugees, should accept refugees and reduce some national law that violates human rights because the humanitarian problems faced by cross-border refugees are the problems and responsibilities of the international community and securitization of refugees will only override this obligation.

\section{E. Balancing Acts of Australian Government}

The two principles of non-refoulement and national security are clearly contradictory in the efforts of protection to international refugees. The nonrefoulement principle prohibits returning refugees to their native countries because they may face persecution again. So far, the non-refoulement principle prohibits countries to return refugees to their home country if they do not want to. Therefore, the process of returning or repatriating international refugees requires a statement declaring their wish to move to a third country or to return to their home country. ${ }^{62}$

Indonesia can be used as an example of a country that succeeded in the case of Vietnamese refugees. Indonesia has formed a program by giving a touch of longing for the refugees so that the refugees would miss the atmosphere of their country. The Indonesian Government set the situation of the Galang Island, an island used as shelter of refugees, to be like Vietnam. It makes the Vietnamese refugees want to return home. So far, Australia has not been successful in adopting the nonrefoulement principle. That is because many Australian national regulations oppose the principle. One of which is the Pacific Solution policy.

The Pacific Solution has raised the pros and cons among the international community. A state's policy to apply a national regulation is the right of the state. They have full sovereignty over their territory and right to apply a national regulation related to its territory. In this case, it covers their territorial sea. Australia is a state that adopts a dualism system. This dualism views international law as lower than national law. ${ }^{63}$ According to this view, national and international laws are two fields of law that are completely different and standalone from one

62 lin Karita Sakharina, Kadarudin, Pengantar Hukum Pengungsi Internasional (Perbedaan latilah Pencari Suaka, Pengungsi Internasional, dan Pengungsi Dalam Negeri), Yogyakarta: Deepublish, 2017, p. 57.

63 Melda Kamil Ariadno, "Kedudukan Hukum Internasional dalam Sistem Hukum Nasional", Jurnal Hukum Internasional, Vol. 5, No. 3, 2008, p. 508. 
another. The underlying assumption is that the application of international law is purely on the hand of the domestic authority. Therefore, national law has a higher position compared to international law. Triepel and Strupp state this opinion.

This dualism is very much related to positivism, which strongly emphasizes the element of agreement of countries. Thus, Australian policy based on the theory is already in accordance with prioritizing national regulations. However, for the record, Australia is still charged with the obligation to accommodate the interests of international refugees because Australia has ratified the 1951 Refugee Convention. Australia has to establish a balance act to accommodate the two principles to meet both international and national obligations. To have a middle method, Australia can place refugees on an outer island that is not yet included in Australian territory and pay attention to the appropriateness of life of refugees. They also have to provide an opportunity for all refugees to submit applications to obtain the refugee status. The Australian Government has done a correct action by placing refugees on its outer islands. However, there are few things that the Australian Government should pay more attention to, namely their treatment of refugees. A country's action to conduct strict screening of every refugee who enters their territory is appropriate because it has a responsibility to protect its citizens from various threats.

A balancing act means the middle method to be taken by a country in handling their obligation so that they can accommodate of both interests of refugees and their national interests. Providing humanitarian protection for refugees is an international obligation for all countries in the world. The United States in protecting its national interests has formed various policies that are considered to violate human rights. A clear example is President Trump's statement that forbids Muslim refugees from entering the United States. ${ }^{64}$ American policy in the form of migration securitization is a response to the national security principle. American securitization is too excessive because it could violate the rights of thousands of international refugees who need protection. American Securitization spread the issue that refugees generally come from Muslim countries and claim the refugees are terrorists. In this case, America does not have a balancing act to accommodate the two important principles in dealing with cross-border refugees.

The example of balancing act is the policy of the Indonesian government. Indonesia is not a country that ratified the 1951 Refugee Convention but Indonesia implements a balancing act well. Indonesia has never carried out a forced repatriation of every refugee who enters the Indonesian maritime border. The Indonesian government has a national instrument even though it is not a member of the country ratifying the 1951 Refugee Convention. Behind the established regulations, Indonesia continues to pay attention to human values to fulfill

64 Adityo Darmawan Sudagung, Rizky Amanda, and Anggia Utami Dewi, "Sekuritisasi Donald Trump terhadap Isu Migrasi dan Perbatasan", paper presented in Seminar Nasional Penerapan IImu Pengetahuan dan Teknologi, Pontianak, 23-24 May 2017. 
international obligations. In this case, the balancing act undertaken by Indonesia does not return refugees to their home countries but asks them to stay in immigration detention houses provided by the Indonesian government. On the other hand, Indonesia regulates national security. Indonesian government regulations aim to secure the sovereign territory of the Indonesian state but still accommodate humanitarian values to protect cross-border refugees.

\section{F. Conclusion}

The principles of national security and non-refoulment are basically contradictory. However, the conclusion that can be drawn from the discussion above is that Australia can take counterbalancing measures to accommodate these two principles in dealing with refugees. Australia is correct in implementing several policies in its national regulations in order to apply the principle of national security because states as sovereign states have the right to protect their country's jurisdiction from outside threats. In addition to Australia, several countries have also implemented national security to protect their countries, namely the United States because based on their experience of being hit by a terrorist attack on September 11, 2010. However, Australia must continue to pay attention to human values in the formation of their national regulations. Then, to fulfill its international obligations, Australia as a country which had ratified the 1951 Refugee Convention, could not violate the non-refoulement principle because this principle is a basic principle and is a peremptory norm in international law. Thus, Australia must continue to accept refugees to their territory with a very strict screening that is in accordance with their national regulations. Australia must still pay attention to humanitarian standards that do not disadvantage refugees in the determination of refugee status. It can also be concluded that, based on some previous policies Australia, has not been able to accommodate these two principles.

\section{References}

\section{Books}

Baylis, John (et.al.), The Globalization of World Politics, Oxford University Press, Oxford, 2008.

Booth, Ken and Steve Smith (eds.), International Relations Theory Today, Polity Press, Cambridge, 1994.

Buzan, Barry, People, States and Fears, an Agenda for International Security Studies in Post-Cold War, Lynne Rienner Publishers, Boulder, 1991.

Gokay, B. and R.B.J. Walker, "War, Terror and Judgement", Frank Cass Publisher, London, 2005.

lin Karita Sakharina and Kadarudin, Pengantar Hukum Pengungsi Internasional (Perbedaan latilah Pencari Suaka, Pengungsi Internasional, dan Pengungsi Dalam Negeri, Deepublish, Yogyakarta, 2017. 
Loescher, Gill, Beyond Charity: International Cooperation and the Global Refugee

Crisis, Oxford University Press, New York, 1996.

Sjaafroedin Bahar, (et.al), Pendidikan Pendahuluan Bela Negara Tahap Lanjutan, Intermedia, Jakarta, 1994.

UNHCR, The State of the World's Refugees 1997-1998, A Humanitarian Agenda,

Oxford University Press, New York, 1998.

Whittaker, Dhavid, Asylum Seeker and Refugees in the Contemporary World, Roudledge, New York, 2006.

\section{Other Documents}

Adityo Darmawan Sudagung, Rizky Amanda, and Anggia Utami Dewi, "Sekuritisasi Donald Trump Terhadap Isu Migrasi dan Perbatasan", paper presented in Seminar Nasional Penerapan IImu Pengetahuan dan Teknologi, Pontianak, 2324 May 2017.

Anggoro Kusnanto, "Keamanan Nasional, Pertahanan Negara dan Ketertiban Umum", Paper Presented at Seminar Pembangunan Hukum Nasional VIII by Badan Pembinaan Hukum Nasional, Departemen Kehakiman dan HAM RI, Denpasar-Bali, 14 July 2003.

Ardi Priyatno Utomo, "Kabar Aksi Terorime di Dua Masjid Australia", https://internasional.kompas.com/read/2019/03/16/16574721/bikinpernyataan-yang-menyalahkan-muslim-senator-australia-ini-dilempar, downloaded on 20 July 2019.

Ayub Torry and Satriyo Kusumo, "Perlindungan Hak Asasi Manusia Pengungsi Internasional", Yustisia, Vol. 1, No. 2, 2012.

BBC News, "Kapal Pencari Suaka Tenggelam di Perairan Jawa", https://www.bbc.com/indonesia/dunia/2013/07/130724_pencari_suaka_austr alia, downloaded on 28 July 2019.

Betts, Katherine, "Boat People and Public Opinion in Australia", People and Place, $\begin{array}{llll}\text { Vol. } 9, \quad \text { No. 2001, } & \end{array}$ file://C:/Users/USER/Downloads/Boatpeoplepublicopinion2001.pdf.

Ceyhan, Ayse, and Anastassia Tsoukala, "The Securitization of Migration in Western Societies: Ambivalent Discourses and Policies." Alternatives, Vol. 27, No. 1, 2002.

Danang Fery Anggriawan, "Pelanggaran Prinsip Non-Refoulment terhadap Pengungsi dan Pencari Suaka pada Kebijakan Operation Sovereign Borders serta Implikasinya bagi Indonesia sebagai Negara Transit," Journal of International Relations, Vol. 2, No. 4, 2016.

Golder, Ben, "Balancing National Security and Human Rights: Assessing the Legal Response of Common Law Nations to the Threat of Terrorism," Journal of Comparative Policy Analysis: Research and Practice, Vol. 8, Issue 1, 2006. 
Goodwin-Gill, Guy S., "Article 31 of the 1951 Convention relating to the Status of Refugees: Non-Penalization, Detention and Protection", https://www.unhcr.org/3bcfdf164.pdf, downloaded on 17 July 2019.

Government of the Netherlands, "Counter Terrorism and National Security Netherland", https://www.government.nl/topics/counterterrorism-andnational-security/national-security, downloaded on 20 July 2019.

Guild, Elspeth, "Anti- \& Counter-Terrorism And Human Rights In Europe", https://www.qmul.ac.uk/law/media/law/docs/events/QMUL-Report-July2018.pdf, downloaded on 17 July 2019.

Hardi Alunaza, Ireng Maulana, and Adityo Darmawan Sudagung, "The Pacific Solution as Australia's Policy towards Asylum Seeker and Irregular Maritime Arrivals (Imas) in The John Howard Era", https://media.neliti.com/media/publications/238227-the-pacific-solution-asaustralia-policy-e4ae21d2.pdf, downloaded on 18 July 2019.

Holm, Ingrid, "Non-Refoulment and National Security," Thesis for Master's Programme on Faculty of Law, Lund University, 2015.

Human Rights Watch, "Human Rights Implications of European Union Internal Security Proposals and Measures in the Aftermath of the 11 September Attacks in the United States", www.hrw.org/press/2001/11/eusecurity-memo.htm, downloaded on 12 July 2019.

Huysmans, J., "The European Union and the Securitization of Migration", Journal of Common Market Studies, Vol. 38, No. 5, 2000, pp. 751-777.

Irawati Handayani, "Accountability for Human Rights Atrocities in International Law: Finding Justice for Past Human Rights Abuses", Thesis for Master's Programme on Faculty of Law, Lund University, 2006.

, "Jus Cogens-International Law and Social Contract," Book Review, Padjadjaran Jurnal Ilmu Hukum, Vol. 3, No. 3, 2016.

, "Responsibility to Protect: A New Form of Humanitarian Intervention?", Padjadjaran Journal of International Law, Vol. 1, No. 1, 2017.

Jun Justinar, "Prinsip Non-Refoulement dan Penerapannya di Indonesia", https://pustakahpi.kemlu.go.id/app/Volume\%203,\%20September-

Desember\%202011_18_23.PDF, downloaded on 28 July 2019.

Lauterpacht, Sir Elihu and Daniel Bethlehem, "The Scope and Content of the Principle of Non-Refoulement: Opinion", https://www.unhcr.org/419c75ce4.pdf, downloaded on 18 July 2019.

Leonard, Sarah, "The Use and Effectiveness and Migration Controls as a CounterTerrorism Instrument in the European Union", Central European Journal of International and Security Studies, Vol. 4, Issue 1, 2010.

Makmur Keliat, "Keamanan Maritim dan Implikasi Kebijakannya bagi Indonesia," Jurnal Ilmu Sosial dan Politik, Vol. 13, No 1, September 2009.

Melda Kamil Ariadno, "Kedudukan Hukum Internasional dalam Sistem Hukum Nasional", Jurnal Hukum Internasional, Vol. 5, No. 3, 2008. 
Nurul Azizah Zayzda, "Sekuritisasi Migrasi Paksa Pengungsi Lintas Batas Indonesia", Journal of Seminar Nasional Hukum Universitas Negeri Semarang, Vol. 3, No. 1, 2017.

Patrnogic, Jovan, "Introduction to International Refugee Law", Paper Presented at Refugee Law Courses, the International Institute of Humanitarian Law, San Remo-Italy, September 1996.

Phillips, Janet, "Social Policy Section on Refugees: Australia's Humanitarian Response", https://www.aph.gov.au/About_Parliament/Parliamentary_Departments/Parlia mentary_Library/pubs/BriefingBook43p/refugees, downloaded on 28 July 2019. Roger, "Apa yang dimaksud dengan Keamanan Nasional (Nasional Security)?", https://www.dictio.id/t/apa-yang-dimaksud-dengan-keamanan-nasionalnational-security/4611, downloaded on 18 July 2019.

Sidratahta Mukhtar, "Keamanan Nasional: Antara Teori dan Prakteknya di Indonesia", http://ejournal.uki.ac.id/index.php/sp/article/view/466, downloaded on 18 July 2019.

Sigit Riyanto, "Prinsip Non-Refoulement dan Relevansinya dalam Sistem Hukum Internasional", Jurnal Mimbar Hukum, Vol. 22, No. 3, 2010, pp. 434 - 449. , "Urgensi Legislasi Hukum Pengungsi dan Kendalanya di Indonesia", Indonesian Journal of International Law, Vol. 2, No. 1, 2004.

Sinnar, Shirin, "Rule of Law Tropes in National Security", http://cdn.harvardlawreview.org/wp-content/uploads/2016/04/1566-1618Online.pdf, downloaded on 17 July 2019.

The Guardian, "Fury as Australian Senator Blames Christchurch Attack on Muslim Immigration", https://www.theguardian.com/world/2019/mar/15/australiansenator-fraser-anning-criticised-blaming-new-zealand-attack-on-muslimimmigration, downloaded on 28 July 2019.

United Nations High Commissioner for Refugees (UNHCR), "Refugee Protection: A Guide to International Refugee Law 1 December 2001," https://www.refworld.org/docid/3cd6a8444, downloaded on 16 October 2019.

Weiner, Myron, "Bad Neighbors, Bad Neighborhoods: An Inquiry into the Causes of Refugee Flows," International Security, Vol. 21, No. 1, 1996, pp. 5-42, https://www.jstor.org/stable/2539107.

Williams, Evan, "Australian Immigration 2001-2013 Exploring attitudes towards asylum seekers and immigrants", Thesis on The Australian National University, 2018.

Yasniar Rahmawati M. Ikaningtyas, "Penanganan Kejahatan People Smuggling yang melibatkan Warga Negara Asing melalui Jalur Laut", Paper presented at Proceeding Interdisciplinary Studies Seminar "Peningkatan Pertahanan Maritim Dan Kerangka Diplomasi Perbatasan dan Ketahanan Nasional Indonesia" Malang, 9 December 2017. 
Zalta, Edward N. (eds.), "Contemporary Approaches to the Social Contract," The Stanford Encyclopedia of Philosophy (Winter Edition)," downloaded on https://plato.stanford.edu/entries/contractarianism-contemporary/\#Distinct, 16 August 2019.

\section{Legal Documents}

Local Regulation DKI Jakarta Number 8 of 2007 on Public Order [Peraturan Daerah DKI Jakarta Nomor 8 Tahun 2007 tentang Ketertiban Umum].

Suresh v Canada, judgement, 2002.

UNHCR's Refugee Protection: A Guide to International Refugee Law 2001.

The 1951 Convention Relating to the Status of Refugees.

The 1967 Protocol Relating to the Status of Refugees. 